\title{
The role of the nurse in improving health literacy among older adults
}

Rola pielęgniarki w zwiększaniu kompetencji zdrowotnych u osób starszych

\section{Tina Razlag Kolar , Boris Miha Kaučič², Tamara Štemberger Kolnik³}

\author{
'University Medical Centre Ljubljana \& College of Nursing in Celje, Slovenia \\ ${ }^{2}$ College of Nursing in Celje, Slovenia \\ UUniversity of Primorska, Faculty of Health Sciences \& College of Nursing in Celje, Slovenia \\ CORRESPONDING AUTHOR/AUTOR DO KORESPONDENCJI: \\ Tina Razlag Kolar \\ University Medical Centre Ljubljana \& College of Nursing in Celje, Slovenia \\ Mariborska cesta 7 \\ 3000 Celje, Slovenia
}

STRESZCZENIE

Słowa kluczowe:

\section{ABSTRACT}

Key words:

\section{ROLA PIELEGNIARKI W ZWIEKSZANIU KOMPETENCJ ZDROWOTNYCH U OSÓB STARSZYCH}

Wprowadzenie. Poziom kompetencji zdrowotnych mówi o tym jak człowiek funkcjonuje w ramach systemu opieki zdrowotnej, jak dobrze rozumie zalecenia związane z ochroną zdrowia, oraz jak dba o własne zdrowie. Jednocześnie może być wskaźnikiem tego, jaki będzie stan zdrowia człowieka w przyszłości. W niniejszym badaniu podjęto próbę ustalenia jaka jest rola pielęgniarki w poprawie kompetencji zdrowotnych u osób starszych.

Materiał i metoda. Badanie miało charakter ilościowy, użyto metody opisowej. Dane zostały zgromadzone za pomocą techniki ankietowej. Jako narzędzie pomiarowe zastosowano ankietę sporządzoną na podstawie przeglądu literatury naukowej, zarówno obcej, jak i krajowej. Użyto doboru celowego nielosowego, do którego zaliczono 148 osób będących w wieku 65 lat lub powyżej, które mieszkają w różnych środowiskach i nie cierpią na demencję. Otrzymano 140 poprawnie wypełnionych ankiet, co stanowi 94\% całości. Wyniki. Osoby starsze biorące udział w badaniu osiągnęły ograniczony poziom kompetencji zdrowotnych w obszarach ogólnych kompetencji zdrowotnych ( $A V=27.0)$, ochrony zdrowia ( $A V=26.2)$, zapobiegania chorobom ( $A V=28.8$ ) i promocji zdrowia ( $A V=26.6)$. W obszarze doradztwa ze strony pielęgniarek osiągnięto wystarczający poziom kompetencji zdrowotnych $(A V=34.6)$.

Wnioski. Kompetencje zdrowotne są jednym z czynników, które w znaczący sposób wpływają na jakość życia osób starszych. Ustalono, że osoby które brały udział w badaniu mają ograniczony poziom kompetencji zdrowotnych. Pielęgniarki mogą znacznie przyczynić się do wzrostu tych kompetencji u osób starszych poprzez edukację zdrowotną i promocję zdrowia. W przyszłości rola pielęgniarek w zakresie promocji zdrowia stanie się bardziej widoczna, zwłaszcza poprzez ich pracę w referencyjnych ośrodkach klinicznych do spraw promocji zdrowia.

kompetencje zdrowotne, osoby starsze, pielęgniarka, promocja zdrowia, jakość życia

Introduction. The level of health literacy tells us how an individual functions within the healthcare system, how well he or she understands the instructions connected to health care, and how he or she looks after own health. However, at the same time, it can be an indicator of how healthy an individual is going to be in the future. In our research we wanted to establish the role of a nurse in improving health literacy among older adults.

Method. The research was based on a quantitative research approach, using descriptive method. Data were collected with the interviewing technique. As a measuring instrument, a questionnaire formed on the basis of the review of domestic and foreign, professional and scientific literature, was used. We used a non-random purposive pattern, in which we included 148 older adults aged 65 years and above, who live in different residential environments and do not suffer from dementia. There were 140 correctly completed questionnaires, which represent a 94\% realization of the sample. The data were analyzed by statistical program SPSS 22.0 . Results. Older adults who took part in the research have achieved limited health literacy in the fields of general health literacy $(A V=27.0)$, healthcare $(A V=26.2)$, disease prevention $(A V=28.8)$ and health promotion $(A V=26.6)$. In the field of nurse counseling they achieved sufficient health literacy ( $\mathrm{AV}=34.6)$.

Discussion and conclusion. Health literacy is one of the factors that significantly affect the quality of life of older adults. We established that older adults who took part in the research have limited health literacy. The nurses can significantly contribute to improving the health literacy of older adults through health-educational work and health promotion. In the future, the role of the nurse in health promotion will have to become more prominent, particularly through their work in reference clinics and reference centers for health promotion. 


\section{INTRODUCTION}

Health literacy is frequently defined as an ability to find, understand and use the information necessary for making health-related decisions, a key challenge for the system of the national healthcare [1]. Nutbeam states, that it represents an important factor of public health as well as of each individual's health and is a fundamental element of patient-orientated healthcare [2]. It influences an individual's health behavior and the use of health services, which consequently influences the medical outcomes and healthcare costs in the society [3]. As a concept, it involves the skills of general literacy as well as the health - connected skills, which demand from an individual to navigate the increasingly complicated system of healthcare, and to refer the patient for self-care and self-treatment [4]. Paasche-Orlow et al. describe this challenge as a minefield for the ageing population, which, beside an inadequate health literacy, faces also multimorbidity and an increasingly fragmented and consumerism-orientated healthcare system which hinders patient's autonomy [5].

For measuring health literacy a number of instruments have been developed, differing in approach, intention and form. Some of them are focused on comprehensive health literacy in population, some serve to establish categories of individuals with low or with high health literacy. The European Health Literacy project consortium (HLS-EU consortium) has developed the instrument called »European Health literacy survey questionnaire« with the label »HLS-EU-Q«[6]. It has been created on the basis of a systematic review of literature as well as of existing definitions and models of health literacy and a conceptual model of health literacy.

Older adults are more susceptible to poor health, as the level of health literacy constantly decreases with advanced age. It is probable that the older adults carry the biggest burden because of an inadequate health literacy, which shows itself as an outcome that is unfavorable to an old person's health [7]. Health literacy of older adults is influenced also by basic socioeconomic factors [3].

Many older adults manage poorly in two special areas of literacy which are health and financial literacy, being necessary for many complex health and financial decisions the elderly face (e.g. planning of retirement, inheritance). The limited level of health literacy among older adults is connected with the increased risk of mortality and disability, higher health expenses and less frequent use of preventive services [8], as well as to the decrease in activities like medication management or understanding complex information about one's treatment [1]. The limited level of financial literacy among older adults is also connected with lower savings and investments, smaller funds and complaints about mental health [8].

Despite an increase in awareness that a limited level of health and financial literacy endangers health, economic security and wellbeing of older adults, until today there has been relatively little known about the factors that cause the limited level of health literacy in advanced old age. Older adults can have lower health literacy levels because of long-term influences, such as limited education or limited knowledge of expressing themselves [8], yet such limited levels of health literacy can also be, according to the findings of a number of researches that did not include dementia patients, linked to an age-related cognitive decline $[9,10,11]$. Besides that, several other resources, such as education, word knowledge, and decision-making manner, contribute to health literacy and are connected to recollection or memory function. The research, however, did not attempt to explain the effects of health literacy on the memory function in the old age $[9,12,13]$. The understanding of the complicated interrelation between aging, recollection or memory function, and connected resources that contribute to health literacy is essential for developing targeted interventions, for improving the health literacy and thus, consequently, for better health and financial outcomes among the already large and fast-growing population of older adults [8].

Considering the increase in chronic non-contagious diseases in the world today and thereby, the presence of multimorbidity of older adults, it is worth to call attention to the importance of health literacy for individual groups of patients with chronic illnesses [14]. In order to control chronic non-contagious diseases, it makes sense to intensively include the patient into medical treatment or management of his illness for which the patient needs functional health literacy, which demands him to understand instructions, use calculations, distinguish if a piece of information is relevant or not, and, of course, to transfer this information into everyday life $[15,16,17]$.

From the point of view of life-long development, »healthy ageing « means good functioning of one's body, the absence of diseases, the preservation of cognitive abilities and an active lifestyle [18]. Health education certainly substantially contributes to ageing quality. Nurses advise older adults on a healthy lifestyle, which includes physical activity, healthy nutrition and endeavors to the absence of smoking and other unhealthy habits. In the case of illness, it teaches them how to improve the quality of living with the disease [19].

It makes sense to connect health literacy as a relatively new concept with health-educational work and health promotion, whereas the basis for successful learning of an individual or a group is represented by the assessment of the level of their health literacy [14]. Health literacy is a prerequisite for encouraging education of patients and enables the individuals to take informed choices about their own health, the health of their families and the community [20]. Nursing care therefore, possesses one of the key tools for improving the health literacy of the population and consequently also for improving the health literacy of older adults through the health educational work and health promotion. The level of health literacy of an individual can serve as a basis for shaping health education of an individual and for targeted contents that needs to improve the self-efficiency of patients by changing their lifestyle habits. By increasing self-efficacy, we are also increasing the level of health literacy, which means that with an effective health education, education for health and health promotion, we can increase the level of health literacy of the entire population [21]. 
The purpose of our research was to establish the role of the nurse in improving the health literacy of older adults. We have formed the following two research aims:

- To establish the level of health literacy among older adults,

- To establish the role of a nurse in improving the health literacy of older adults.

On the basis of the defined research problem we have formed the following two research questions:

- What is the level of health literacy among older adults?

- What is the role of a nurse in improving the health literacy of older adults?

\section{METHODS}

Our research was based on a quantitative research approach, using descriptive method. Data were collected with the interviewing technique.

\section{Description of the instrument}

The research was conducted by using a structured instrument in the form of an anonymous written questionnaire, which was developed on the basis of domestic and foreign professional and scientific literature review $[6,22,23,24]$ and was divided into three sections. At first, we used an instrument authored by Zavod Viva - Institute Viva [22], which the authors developed after the model of »European Health Literacy Survey Questionnaire - HLS-EU-Q47« [6]. It was partially modified with regard to the specifics of the Slovene space, for which written consent was obtained and adapted to the older adult. The questions that were not directly connected with the study (the explanation of technical terms) were left out, and 3 original questions were added - these are the questions number 5,8 and 13 . The question 19 , which relates to work environment, did not seem relevant to the older adult and was left out and replaced by the question 22, which was taken from HLS-EU-Q47 [6]. The respondents were asked to circle the number next to the statement or answer that was applicable to them. Before carrying out the research, we tested comprehensibility of the measuring instrument. All 28 questions of the first section of the questionnaire were posed as direct questions, and a 4-level scale was used to assess the respondents' viewpoints, where 1 meant - very easy, 2-easy, 3-difficult, 4-very difficult. Demographic questions were stated at the end of the questionnaire.

\section{Sample}

We used a non-random, purposive sample with an age restriction of respondents being 65 years old and above. The study included older adults who live in urban and rural areas of the Savinjska region, and older adults who live in three nursing homes in the wider Savinjska region. The sample included randomly selected older adults who met the pre-specified criterion of age and were not diagnosed with dementia. A total of 148 questionnaires were distributed. As many as 48 questionnaires were distributed in the nursing homes, 50 questionnaires in rural areas, and 50 in urban areas. Out of the total of 148 distributed questionnaires, all 148 were returned, out of which 8 were invalid, which means that 140 were valid. The realization of the sample was therefore $94 \%$.

\section{Description of data collection and analysis}

Before carrying out the research we obtained written consent in all three nursing homes where we conducted the survey. Anonymity was ensured in the following way: after the completion of the survey, respondents put questionnaires in envelopes and next placed them in a closed box. To complete the questionnaire, the respondents needed 30 minutes. All the participants gave informed consent, and were informed that they may withdraw from the research at any time. The data obtained were statistically analyzed by the program MS Excel 2010 and SPSS 22.0

\section{Ethical aspect of the research}

In carrying out the research all ethical aspects were ensured: the principle of usefulness, harmlessness, confidentiality, fairness, truthfulness and the principle of security. To all the respondents the right to full clarification and the right to privacy, anonymity and confidentiality were ensured. The principles of the Code of Ethics in Nursing Care Slovenia [25] and the principles of the Oviedo Convention were considered. Prior to the conduction of our research, we obtained the approval of the competent Board of the College of Nursing in Celje, number 87/2015-DIPL_TRK, dated October $5^{\text {th }}, 2015$.

\section{RESULTS}

The reliability of the health literacy indexes was assessed by Cronbach alpha coefficients, which are relatively high for all indexes; the highest is the coefficient for general health literacy $(0.926)$, whereas $»$ nurse counseling " coefficient is the lowest and amounts to 0.707 . All the elements correlate with more than 0.3 , what indicates that all of the elements are good enough to make up the indexes.

Indexes of health literacy were divided into 4 groups: (1) insufficient health literacy with the index value of $0-25$, (2) problematic health literacy with the index value of 26-29, (3) sufficient health literacy with the index value of 30-36 and (4) excellent health literacy with the index value of 37-50. When interpreting the results, we use the term limited health literacy; we got it by combining insufficient and problematic health literacy into one class.

Tab. 1. General health literacy of older adults.

\begin{tabular}{|l|c|c|c|c|}
\hline \multirow{2}{*}{\multicolumn{1}{|c|}{ Type of health literacy }} & \multicolumn{2}{|c|}{ Index value } & \multirow{2}{*}{ AV } & \multirow{2}{*}{ SD } \\
\cline { 2 - 3 } & $\mathbf{m i n}$ & $\mathbf{m a x}$ & & \\
\hline General health literacy & 8.7 & 48.0 & 27.0 & 7.8 \\
\hline Health literacy in the field of healthcare & 8.3 & 48.6 & 26.2 & 7.9 \\
\hline Health literacy in the field of disease prevention & 0.0 & 50.0 & 28.8 & 9.0 \\
\hline Health literacy in the field of health promotion & 5.6 & 50.0 & 26.6 & 8.7 \\
\hline Nurse, Counseling & 11.1 & 50.0 & 34.6 & 8.5 \\
\hline
\end{tabular}

$\mathrm{AV}$ : average value, SD: standard deviation, min: minimal value of health literacy index max: maximal value of health literacy index. 
The table 1 shows general health literacy among older adults, from which it is visible, that among the respondents the lowest achieved value in the field of health literacy is in the field of healthcare, $(\mathrm{AV}=26.2, \mathrm{SD}=7.9)$, whereas the highest achieved value is in the field of nurse counseling ( $\mathrm{AV}=34.6 ; \mathrm{SD}=8.5)$. The highest variability of the achieved results in the field of health literacy is in the field of disease prevention $(\mathrm{SD}=9)$, whereas the lowest variability is in the field of general health literacy $(\mathrm{SD}=7,8)$.

The participation of an elderly person in the conversation with a nurse and asking questions (according to the respondent's gender): In our research we have established that the participation in the conversation with a nurse and asking questions was easy for $64.3 \%$ of the respondents, for $17.9 \%$ this was very easy, whereas for $15.7 \%$ of the respondents this was difficult, and for only $2.1 \%$ it was very difficult. Among the respondents who answered that it was "very difficult « to participate in the conversation with a nurse, there were no men. From the resulting statistical analysis we cannot conclude, that the gender of the respondent influences the level of complexity perception of the participation in the conversation with a nurse and asking questions $\left(\chi_{2}=3.620 ; \mathrm{p}=0.306\right)$.

Understanding general instructions given by the nurse according to the respondent's gender: We established that $54.3 \%$ of older adults can understand the general instructions of the nurse easily, for $37.1 \%$ understanding the general rules was very easy, for $7.1 \%$ understanding the general instructions was difficult, and for $1.4 \%$ very difficult. Among the respondents who answered »very difficult« there were only women. From the resulting statistical analysis we cannot conclude, that the gender of the respondent influences the understanding of general instructions given by a nurse, such as the instructions during drawing blood. ( $\chi 2=2.777 ; \mathrm{p}=0.427)$.

Understanding instructions given by the nurse on a healthy lifestyle according to the respondent's gender: The analysis of the results showed that for $63.6 \%$ of older adults understanding the instructions of the nurse on a healthy lifestyle was easy, for $19.3 \%$ this was very easy, whereas $14.3 \%$ of respondents stated that the instructions of the nurse on a healthy lifestyle were difficult to understand, and for $2.9 \%$ they were very difficult to understand. From the resulting statistical analysis we cannot conclude that gender of the respondent influences the understanding of the instructions given by a nurse on a healthy lifestyle, $(\chi 2=1.703 ; \mathrm{p}=0.636)$.

Tab. 2. Participation of an elderly person in the conversation with the nurse and asking questions according to the level of education of the respondent.

\begin{tabular}{|l|c|c|}
\hline \multicolumn{1}{|c|}{ Claim } & r & p \\
\hline $\begin{array}{l}\text { Participation in the conversation with the nurse and asking } \\
\text { questions }\end{array}$ & -0.157 & 0.064 \\
\hline
\end{tabular}

$r$ : Spearman correlation coefficient, $p$ : level of trust
The table 2 shows the participation of an older adult in conversation with a nurse and asking questions according to the level of education of the respondent. From the resulting statistical analysis we cannot conclude whether the level of education is a factor influencing the participation in the conversation with the nurse at the level of trust of $5 \%(\mathrm{p}=0.005)$.

Tab. 3. Understanding general instructions and instructions on a healthy lifestyle, which the nurse gives to an elderly person according to the level of education of the respondent.

\begin{tabular}{|l|c|c|}
\hline \multicolumn{1}{|c|}{ Claim } & r & p \\
\hline $\begin{array}{l}\text { Understanding general instructions of the nurse } \\
\text { (e.g. during drawing blood) }\end{array}$ & -0.260 & 0.002 \\
\hline Understanding instructions of the nurse on a healthy lifestyle & -0.278 & 0.001 \\
\hline
\end{tabular}

$r$ : Spearman correlation coefficient, $p$ : level of trust

The table 3 shows the understanding of the general instructions of a nurse and understanding of the instructions of a nurse about a healthy lifestyle according to the level of education of an older adult. From the resulting statistical analysis we can conclude that the respondents with lower levels of education experience more difficulties in understanding the instructions of the nurse $(\mathrm{p}=0.002)$ and that they also experience more difficulties in understanding the instructions of the nurse on a healthy lifestyle. $(\mathrm{p}=0.001)$.

\section{DISCUSSION}

The level of health literacy tells us how an individual understands the instructions that he or she receives within the healthcare system, how he or she functions within the healthcare system, and that is why with its help it is possible to predict, how healthy an individual is going to be in future [26]. That is extremely important when taking into consideration more vulnerable population groups, such as older adults, the group which can nowadays be linked to multimorbidity, loneliness and related health and social problems. In frame of our research we have in the first place tried to establish the level of health literacy in older adults included in the sample. We have established that the general health literacy in older adults, who have participated in our research, is limited. What is also limited, is health literacy in the fields of healthcare, disease prevention and health promotion. The situation is not promising; it was, however, expected, as the limited level of health literacy is more frequent in more vulnerable population groups, such as older adults, people with lover levels of education and others $[3,7,27]$.

We also included in our research the so called concept of the nurse in connection with the health literacy of older adults, their lifestyle and the influence of demographic variables on the so-called »concept of the nurse«. In frame of our research we wished to determine the health literacy of elderly people in the field of nurse counseling, where old people, included in the research, achieved sufficient health literacy. The originality of the research is in the studying of the concept of the nurse. We wanted 
to establish the role that the nurses play in improving health literacy. We cannot compare the findings of our research to other research work, as the research is highly original, but we can confirm the importance of the role of the nurse through the literature review. From our research it is therefore visible, that elderly people understand the general instructions of a nurse well, the same as the instructions of a nurse on a healthy lifestyle. They, as well, do not have any difficulties in participating in the conversation with a nurse or asking questions. From our research it can therefore be concluded, that a nurse has a good starting point for health-educational work with an older adult person. The contribution of a nurse to increase in the level of health literacy in a patient can be, irrespective of the patient's medical condition, substantial, as through every interaction with a patient the relationship works in a health-educational manner and educates the patient, either in a planned or not planned manner [23, 28, 29]. For patients with low or limited levels of health literacy, the health-educational work is of extreme importance, and it is even more efficient when conducted individually [30]. A nurse plays a key role in the health-educational process, as he or she spends most time with the patient on all the three levels of healthcare activity. This enables a nurse to recognize the suitable moment, when the patient is ready, able and motivated to learn [31]. Health education can therefore substantially contribute to quality of ageing [19] and therefore the nurse should promote a healthy lifestyle among elderly people.

We are of the opinion that the role of a nurse in health promotion should be strengthened and become more prominent. Perhaps it would be meaningful to think about new forms of work in the field of health promotion in older adults. In addition to the reference clinics and reference centers for health promotion, we would establish counseling centers for elderly adults in the local communities, where we would offer additional health literacy training, promote a healthy lifestyle in elderly age (healthy nutrition and physical activity), promote autonomy and independence of people this age, and promote their safety and prevention against non-contagious chronic diseases. With the synergy of knowledge and experience in form of interprofessional cooperation of various experts physicians, physiotherapists, work therapists and social gerontologists - we would offer older adults a holistic treatment, which would contribute to a healthy, active and high quality ageing. Such form of counseling centers should be also available to all the older adults living in nursing homes, as they are deprived of the treatment by a reference nurse. According to the findings of our survey, the older adults who live in nursing homes and are functionally able, would certainly need health-educational treatment that would help them change their unhealthy lifestyle habits and postpone or slow down the occurrence of non-contagious chronic diseases. It is of utmost importance, that nursing students achieve skills in the field of therapeutic communication already during their studies and master the understanding of the holistic approach towards an older adult.

\section{CONCLUSIONS}

Health literacy is one of the factors that significantly affect the life quality of the elderly. The results of our research show that older adults, who took place in our research, have limited health literacy. Therefore, there exists a danger, that an insufficient health literacy in this already vulnerable population group, will show itself in the form of the incorrect use of medication, in the incorrect use or lack of use of health services, in poor management of chronic diseases, in an unsuitable response to the emergency situations, in poorer health condition of older adults, in the lack of self-efficacy and confidence, and in a financial burden for the individual as well as for the society, which consequently leads to even bigger social inequalities. We are of the opinion that the present situation is certainly a sign, which shows that older adults need health-educational treatment and health promotion, with which we are going to improve the level of health literacy among them, and by all means it would be necessary to develop the norms for health literacy for general Slovene population.

Nurses are the ones who can contribute to the increase in health literacy in all areas of their operation. Because in the process of treating diseases and in the process of disease prevention nurses are the ones who spend the most time with an older person, they can do a lot of good in the field of health promotion and can inspire older adults to change their behavioral habits and unhealthy lifestyle. With the choice of suitable medical education techniques, a nurse will educate and empower an older people, so that they can recognize how their lifestyle influences their health and what risk factors they may face. An older adult, who will be educated and empowered, will know how to keep, strengthen and achieve their health, and in the case of an illness he or she will know how to effectively navigate the health system - such an older adult is health literate.

The contribution of a nurse to the increase in health literacy of a patient can be, irrespective of the patient's health condition or age, substantial, as the nurse works in a health-educational way through every interaction with the patient, either planned or unplanned. The success of a nurses' work does not depend merely on their knowledge or the achieved education level, but on their social and cultural capital.

The role of a nurse is in modern society facing a number of challenges which means that this role is becoming more and more prominent. The role of the nurse is not only important at times when life activities of the patient need to be provided, but also in ensuring prevention.

The research was conducted on a small sample of older adults, only the quantitative research approach was used. In the future it would be necessary to develop an instrument for measuring/establishing health literacy of older adults and validate it on the larger sample of the Slovenian population of older adults. It would also be necessary to think about the research method (qualitative research approach, focus groups etc.). 


\section{REFERENCES}

1. Chin J, Madison A, Gao X, et al. Cognition and Health Literacy in Older Adults' Recall of Self-Care Information. The Gerontologist. 2015. Doi:10.1093/geront/gnv091. Available at: http://gerontologist.oxfordjournals.org/content/early/2015/07/18/ geront.gnv091.full [10. 02. 2016]

2. Nutbeam D. Health literacy as a public goal: a challenge for contemporary health education and communication strategies into the 21st century. Health Promot Int. 2000; 15 (3): 259-267. 10.1093/heapro/15.3.259.

3. Sørensen K, Van der Broucke S, Fullam J, et al. Health literacy and public health: A systematic review and integration of definitions and models. BMC Public Health. 2012; (12): 80-92. Doi: 10.1186/1471-2458-12-80.

4. Liechty JM. Health literacy: critical opportunities for social work leadership in health care and research. Health and social work. 2011; 36(2): pp. 99-107. Doi: 10.1093/ hsw/36.2.99.

5. Paasche-Orlow MK, Parker RM, Gazmararian JA, et al. The prevalence of limited health literacy. J Gen Intern Med. 2005; 20: 175-84. Doi: 10.1111/j.15251497.2005.40245.x

6. Sørensen K, Van der Broucke S, Pelikan JM, et al. Measuring health literacy in populations: illuminating the design and development process of the European Health Literacy Survey Questionnaire (HLS-EU-Q). BMC Public Health. 2013; (13): 948-957. Doi: 10.1186/1471-2458-13-948

7. Toçi $E$, Burazeri $G$, Jerliu N, et al. Health literacy, self-percieved health and selfreported chronuc morbidity among older people in Kosovo. Health Promotion International. 2015. 2015; 30(3): 667-674. Doi: 10.1093/heapro/dau009

8. Boyle PA, Yu L, Wilson RS, et al. Cognitive decline impairs financial and health literacy among community-based older persons without dementia. Psychol Aging 2013. 2013; 28(3): 614-624. Doi: 10.1037/a0033103

9. Baker DW, Wolf MS, Feinglass J, Thompson AT. Health Literacy, Cognitive Abilities, and Mortality Among Elderly Persons. Journal of General Internal Medicine. 2006. 2006; 23(6):723-726. Doi: 10.1007/s11606-008-0566-4

10. Bennett JS, Boyle PA, James BD, Bennett DA. Correlates of health and financial literacy in older adults without dementia. BMC Geriatrics. 2012; 12(30). Doi: 10.1186/1471-2318-12-30 Available at: http://www.biomedcentral.com/14712318/12/30 [1. 8. 2014].

11. Wolf MS, Curtis LM, Wilson EAH, et al. Literacy, Cognitive Function, and Health: Results of the LitCog Study. Journal of General Internal Medicine. 2012; 27(10): 1300-1307. Doi: 10.1007/s11606-012-2079-4

12. Baker DW. The meaning and the measure of health literacy. Journal of General Internal Medicine. 2006; 21(8):878-83. Doi: 10.1111/j.1525-1497.2006.00540.x

13. DeWalt DA, Berkman ND, Sheridan S, et al. Literacy and Health Outcomes. Journal of General Internal Medicine. 2004; 19(12):. 1228-1239.

14. Štemberegr Kolnik T, Babnik K. Oblikovanje instrumenta zdravstvene pismenosti za slovensko populacijo: rezultati pilotske raziskave. [In:] Železnik, D., et al., eds. Inovativnost v koraku s časom in primeri dobrih praks: zbornik predavanj z recenzijo. Slovenj Gradec: Visoka šola za zdravstvene vede; 2012.p.248-255.

15. Jeppesen KM, Coyle JD, Miser WF. Screening questions to predict limited health literacy: a cross-sectional study of patients with diabetes mellitus. Annals of family medicine. 2009; 7(1): 24-31. Doi: 10.1370/afm.919

16. Cavanaugh KL. Health literacy in diabetes care: explanation, evidence and equipment. Diabetes Management. 2011; 1(2): 191-199. Doi: 10.2217/dmt.11.5

17. Xu WH, Rothman RL, Li R, et al. Improved self-management skills in Chinese diabetes patients through a comprehensive health literacy strategy: study protocol of a cluster randomized controlled trial. Trials. 2014; (15): 498-507. Doi: 10.1186/17456215-15-498

18. Špendal S. Recognizing individual needs of the elderly with disabilities in occupational activity centers for inclusion in more appropriate programs in old age. [In:] Ovsenik, M. \& Ovsenik, R. eds. Quo vadis ageing?. Maribor: Alma Mater Europaea - Evropski center; 2015.p. 121-137.

19. Verbič D, Zupančič V. Vloga zdravstvenih delavcev pri vzgoji za kakovostno staranje. [In:] Babnik, K, Kocbek, M, eds. Raziskovanje študentovzdavstvenih vedin evropsko leto aktivnega staranja ter medgeneracijske solidarnosti: zbornik prispevkov. 4. študentska konferenca s področja zdravstvenih ved, Izola, 25. maj 2012. Založba univerze na Primorskem Koper; 2012.p.189-196.

20. Sørensen K, Schuh B, Stapleton G, Schröder-Bäck P. Exploring the ethical scope of health literacy - a critical literature review. Albanian medical journal. 2013; (2): 7183.

21. Štemberger Kolnik T, Babnik K. Modeli zdravstvene pismenosti: razumevanje individualnih dejavnikov zdravja in z zdravjem povezanega vedenja. [In:] Železnik $D$, et al., eds. Sedanjost in prihodnost zdravstvenih ved v času globalnih sprememb: zbornik predavanj z recenzijo. Znanstvena konferenca $z$ mednarodno udeležbo $\mathrm{s}$ področja zdravstvenih ved, 17. September 2013. Laško. Visoka šola za zdravstvene vede. Slovenj Gradec; 2013.p.99-107.
22. Zavod Viva. Projekt Govori jezik zdravja za dvig zdravstvene pismenosti v Sloveniji. Ljubljana; 2013.

23. Hozjan D, Babnik K, Štemberger Kolnik T. Zdravstvena pismenost in zaznana kompetentnost na področju zdravja med študenti zdravstvene nege. [In:] Štemberger Kolnik, T., et al., eds. Zdravstvena nega v javnem zdravju: zbornik prispevkov z recenzijo. Druga znanstvena konferenca z mednarodno udeležbo, Izola, 31. januar 2014. Univerza na Primorskem. Koper; 2014.p.179-186.

24. Hozjan D, Babnik K, Štemberger Kolnik T, Kerkorč M. Povezanost individualnih demografskih značilnosti in zdravstvene pismenosti z zdravim življenjskim slogom. [In:] Hozjan, D. ed. Izobraževanje za 21. stoletje - ustvarjalnost v vzgoji in izobraževanju. Univerzitetna založba Annales. Koper; 2014.p.505-517.

25. Zbornica zdravstvene in babiške nege Slovenije-Zveza strokovnih društev medicinskih sester, babic in zdravstvenih tehnikov Slovenije. Kodeks etike v zdravstveni negi in oskrbi Slovenije. Ljubljana; 2014.

26. Sørensen K, Pelikan JM, Röthlin F, et al. Health literacy in Europe: comparative results of the European health literacy survey (HLS-EU). European Journal of Public Health. 2015; 25(6): 1053-1058. Doi:10.1093/eurpub/ckv043

27. Van Servellen G. Communication skills for the health care profesionals: concepts, practice and evidence. 2nd edition. Jones and Barlett. Sudbury; 2009.p.203.

28. Štemberger Kolnik T. Opolnomočenje pacienta s kronično boleznijo. In: Kvas, A. ed. Zdravstvena vzgoja - moč medicinskih sester: zbornik prispevkov z recenzijo. Društvo medicinskih sester, babic in zdravstvenih tehnikov. Ljubljana; 2011. p.119127.

29. Babnik K, Bratuž A, Štemberger Kolnik T. Zdravstvena pismenost: stanje koncepta in nadaljnji razvoj z vključevanjem zdravstvene nege. Obzornik zdravstvene nege 2013; 47(1): 62-73.

30. Rothman RL, DeWalt DA, Malone $R$, et al. Influence of patient literacy on the effectiveness of a primary care-based diabetes disease management program. JAMA. 2004; 292(14):1711-1716. Doi: 10.1001/jama.292.14.1711

31. Kvas A. Medicinske sestre na področju promocije zdravja in zdravstvene vzgoje: kje smo, kam gremo? In: Kvas, A. ed. Zdravstvena vzgoja - moč medicinskih sester : zbornik prispevkov z recenzijo. Društvo medicinskih sester, babic in zdravstvenih tehnikov. Ljubljana; 2011.p.37-47.

Manuscript received: 21.11.2016

Manuscript accepted: 12.03.2017

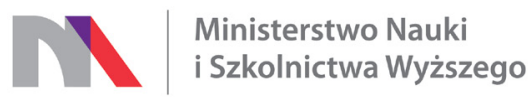

„Konsultacje z zagranicznymi naukowcami i wprowadzenie dwujęzycznych (j. polski/angielski) treści do czasopisma Pielęgniarstwo XXI wieku" finansowane w ramach umowy 547/P-DUN/2016 ze środków Ministra Nauki i Szkolnictwa Wyższego przeznaczonych na działalność upowszechniającą naukę. 